\title{
Cytokines as potential therapies for human immunodeficiency virus infections
}

\author{
ROBERT W SIDWELL PhD, JOHN D MORREY PhD, REED P WARREN PhD
}

RW SiDWELl, JD MORREY RP WARREN. Cytokines as potential therapies for human immunodeficiency virus infections. Can $\mathbf{J}$ Infect Dis 1994;5(Suppl A):28A-35A. Cytokines are attracting increased interest as potential therapies for human immunodeficiency virus (HIV) infections. This attraction has particularly arisen as these cytokines have become more commercially available through recombinant technologies. This review focuses on the effects of these biological response modifiers on preclinical HIV and related retrovirus infections. Cytokines that have particularly been considered for HIV disease control include: interferons $-\alpha,-\beta$ and $-\gamma$; interleukins $-2,-3,-4,-6$ and -7 ; tumour necrosis factors $-\alpha$ and $-\beta$; and the colony stimulating factors. Efficacy has especially been seen when these cytokines have been used in combination with the more conventional antiviral agents. Due to the many biological functions exerted by cytokines and their interweaving of biological effects with other cytokines, they appear to have the potential to both inhibit as well as enhance viral infections, depending upon how they are used, and caution is therefore urged in their use.

Key Words: Colony stimulating factor, Cytokines, Human immunodeficiency virus, Interferon, Interleukin, Tumour necrosis factor

\section{Les cytokines et leur rôle potentiel dans le traitement des infections au VIH}

RÉSUMÉ : Les cytokines font l'objet d'un intérêt croissant à titre de traitement potentiel contre les infections au virus de l'immunodéficience humaine (VIH). Cet intérêt est notamment dû au fait que ces cytokines sont devenues plus accessibles commercialement par l'entremise du génie génétique. Cette revue porte sur les effets des modificateurs de la réponse biologique sur un viH préclinique et les infections à rétrovirus associées. Ces cytokines, qui ont été particulièrement pressenties dans la lutte contre la maladie au VIH, comprennent les interférons- $\alpha$, $-\beta$ et $-\gamma$, les interleukines- $2,-3,-4,-6$, et -7 ; les facteurs de nécrose tumorale- $\alpha$ et $-\beta$ et les facteurs stimulateurs des colonies. L'efficacité a notamment été observée lorsque ces cytokines ont été utilisées en association avec des antiviraux plus classiques. À cause des nombreuses fonctions biologiques exercées par les cytokines et de leurs effets biologiques complexes en interaction avec d'autres cytokines, elles semblent dotées du pouvoir d'inhiber et d'exacerber les infections virales selon la façon dont elles sont utilisées. Il faut donc faire preuve de beaucoup de circonspection lorsqu'on les emploie.

Institute for Antiviral Research, Utah State University, Logan, Utah, USA

Correspondence and reprints: Dr RW Sidwell, Institute for Antiviral Research, Utah State University, Logan, UT 84322-5600, USA. Telephone (801) 750-1888, Fax (801) 750-3959 
A BROAD SPECTRUM OF AGENTS HAS BEEN CONSIDERED AS therapies for human immunodeficiency virus (HIV) infections in humans. Among these has been a variety of materials whose primary mechanisms of action are as immunomodulators. Using immunomodulation as an approach for such therapy would seem appropriate since the major manifestation of HIV infection is immunodeficiency.

Among the immunomodulators that have been particularly considered are the cytokines. Balkwill and Burke (1) have offered the following definition for these substances: "Cytokine is one term for a group of protein cell regulators, variously called lymphokines, monokines, interleukins and interferon, which are produced by a wide variety of cells in the body, play an important role in many physiological processes, are involved in the pathophysiology of a range of diseases, and have therapeutic potential."

The cytokines often have major effects on the hematopoietic and immune systems (2), which point to their potential as therapies or for the prevention of infectious complications in the immunosuppressed patient. These same effects, however, if inappropriate to the disease manifestation, may also result in adverse effects that need to be considered.

Recombinant DNA technology has allowed many cytokines to be synthesized efficiently, which enhances their potential as antiviral agents. Of the many cytokines known, research efforts to elucidate their antiviral activity have focused primarily on those listed in Table 1 .

This review focuses on the reported nonclinical experiments with these cytokines. The experiments are oriented towards defining the potential of cytokines as therapies for AIDS.

\section{INTERFERONS}

More work has been accomplished with interferons (IFN) than with any other cytokine in studying their potential for therapy of virus diseases. Space does not allow an in-depth review of the vast amount of literature available on IFN; the focus of this review is on the potential of type 1 IFN ( $\alpha$ and $\beta$ ) and type 2 IFN $(\gamma)$ to inhibit HIV infections or those of related retroviruses.

Mechanisms of antiviral effect: All three species of IFN markedly inhibit HIV replication in vitro, as well as inhibiting the replication of other retroviruses (3-11). IFNS exert a spectrum of in vitro effects on these viruses, including inhibition of assembly, maturation and release $(12,13)$. When cells are chronically infected, a late stage of viral morphogenesis is inhibited, which results in either a significant inhibition of virus production or a release of fewer noninfectious particles $(4,5,9)$. In a study in which viral production was slowed, an accumulation of virus particles occurred on the cell surface and in cytoplasmic vacuoles (10). This may be a result of IFN effects on the fluidity of the plasma membrane

\section{TABLE 1 \\ Cytokines studied for efficacy against experimentally induced virus infections}

Interferon- $\alpha$
Interferon- $\beta$
Interferon- $\gamma$
Interleukin-2
Interleukin-3
Interleukin-4
Interleukin- 6 (Interferon- $\beta_{2}$ )
Interleukin-7
Tumour necrosis factor- $\alpha$
Tumour necrosis factor- $\beta$
Granulocyte-macrophage colony stimulating factor
Macrophage-specific colony stimulating factor
Granulocyte-specific colony stimulating factor

(11,13). Smith et al (10) showed that inhibition of HIV production by IFN- $\alpha$ in chronically infected cells may have been primarily a result of decreased cell growth since reverse transcriptase and the number of viable cells decreased at similar rates. All IFNs are known to induce $2^{\prime}, 5^{\prime}$ A synthetase, which indirectly activates endoribonucleases that may degrade viral RNA (14), presenting another potential mechanism for their action.

IFNS are significant inhibitors of murine retrovirus disease (15-17). The antiviral efficacy may be attributable to both more traditional antiviral effects, as noted above, and their actions as immunomodulators. IFN- $\alpha$ has been shown to enhance natural killer (NK) cell activity and antibody-dependent cell-mediated cytotoxicity (18). Pertinent to IFN' immunomodulatory effects are some recent experiments by the present authors using human recombinant IFN- $\alpha-A / D$ (Hoffman La Roche, Inc, New Jersey) against Friend virus (FV) infection in mice. In one experiment, the mice used were (B10.11 $\times 11 / \mathrm{WySn}_{\mathrm{S}} \mathrm{F}_{1}$ hybrids, which can produce high titres of FV-neutralizing antibodies, but are relatively low in FV-specific cytotoxic $\mathrm{T}$ lymphocyte activity (19-21). The IFN- $\alpha$ treatment $(10,000 \mathrm{U} /$ mouse/day) inhibited splenomegaly and resulted in some reduction of virus titre, particularly in plasma. When the experiment was repeated using $\left(\mathrm{B} 10.11 \times 11\right.$. By)F $F_{1}$ hybrid mice, which have the ability to produce FV-specific neutralizing antibodies and to have cytotoxic T cell activity (19), $10,000,5000$ and $2500 \mathrm{U} / \mathrm{mouse} /$ day of the same IFN- $\alpha$ rendered a significantly enhanced antiviral effect especially manifested in reduced spleen and plasma virus titres. Both mouse strains exhibit a strong NK cell response. These data suggest that the activity of this cytokine may be linked to the cytotoxic $\mathrm{T}$ cell response.

The mechanism(s) by which IFNs act synergistically with more standard antiviral drugs is unclear. The differences in specific mechanisms by which virus is being inhibited by the two substances used in combi- 


\section{TABLE 2}

Retrovirus inhibition studies using interferon in combination with other agents

\begin{tabular}{|c|c|}
\hline Action & Reference \\
\hline $\begin{array}{l}\text { IFN- } \alpha+\text { AZT or PFA synergistically inhibited HIV } \\
\text { in PBLs }\end{array}$ & 58,59 \\
\hline $\begin{array}{l}\text { IFN- } \alpha+\text { HEPT synergistically inhibited HIV in } \\
\text { MT- } 4 \text { cells and PBLs }\end{array}$ & 60 \\
\hline $\begin{array}{l}\text { IFN- } \alpha+\text { protease inhibitor synergistically inhibited } \\
\text { HIV in PBLs }\end{array}$ & 61 \\
\hline $\begin{array}{l}\text { IFN- } \alpha+\text { AZT synergistically inhibited HIV } \\
\text { transmission from U9-111B cells to cocultivated } \\
\text { U937 cells }\end{array}$ & 62 \\
\hline $\begin{array}{l}\text { IFN- } \alpha+\text { AZT synergistically inhibited Rauscher } \\
\text { virus infection in mice }\end{array}$ & 15 \\
\hline $\begin{array}{l}\text { INF- } \alpha+\text { AZT was more effective than IFN- } \alpha \text { or } \\
\text { AZT alone in reducing FeLV viremia and } \\
\text { preventing FeLV in cats }\end{array}$ & 26 \\
\hline $\begin{array}{l}\text { IFN- } \alpha+\text { AZT + adoptive transfer of activated lym- } \\
\text { phocytes reversed an established FeLV infec- } \\
\text { tion in cats. Antiviral effect of IFN- } \alpha \text { alone was } \\
\text { limited by production of antibodies to IFN- } \alpha\end{array}$ & 25,28 \\
\hline $\begin{array}{l}\text { IFN- } \alpha+\text { AZT failed to protect monkeys from SIV } \\
\text { challenge, but reduced virus replication } \\
\text { better than AZT alone }\end{array}$ & 25 \\
\hline $\begin{array}{l}\text { IFN- } \alpha+\text { D4T synergistically inhibited Friend virus } \\
\text { replication in vitro and enhanced the inhibi- } \\
\text { tion of splenomegaly, spleen and plasma virus } \\
\text { titres and hematocrit increase in Friend virus- } \\
\text { infected mice. Enhanced NK cell activity was } \\
\text { seen with the IFN + D4T treatments }\end{array}$ & 23 \\
\hline $\begin{array}{l}\text { IFN- } \beta+\text { AZT synergistically inhibited HIV- } 1 \text { in HeLa } \\
\text { T4 and MT- } 2 \text { cells }\end{array}$ & 25 \\
\hline $\begin{array}{l}\text { IFN- } \gamma+\text { AZT synergistically inhibited LP-BM5 virus in } \\
\text { macrophages }\end{array}$ & 63 \\
\hline $\begin{array}{l}\text { IFN- } \gamma+\text { TNF- } \alpha \text { synergistically induced HuT78 and } \\
\text { RPMI } 788 \text { cell resistance to HIV, reduced HIV } \\
\text { RNA and p24 synthesis, inhibited production of } \\
\text { infectious HIV, killed cells already infected with } \\
\text { HIV and inhibited production of HIV mRNA in } \\
\text { chronically infected cells }\end{array}$ & 64 \\
\hline $\begin{array}{l}\text { IFN- } \gamma+\text { human lactoferrin synergistically inhibited } \\
\text { Friend virus-induced splenomegaly in mice }\end{array}$ & 65 \\
\hline
\end{tabular}

AZT Zidovudine; D4T 2'3'-didehydro-2 3'dideoxythymidine; FelV Feline leukemia virus; HEPT 1(2-hydroxyethyoxy)methyl)-6-(phenylthio)thymine; HIV Human immunodeficiency virus; IFN Interferon: NK Natural killer; PBLS Peripheral blood lymphocytes; PFA Phosphonoformate; SIV Simian immunodeficiency virus

nation explain the effects seen, at least in part, particularly in the in vitro experiments cited. It is possible, however, that the IFNS are providing at least a partial restoration of a failing immune system in the retrovirus-infected animals. The recent report of Shafik et al (22) that IFN- $\beta$ treatment appeared to inhibit the rate of zidovudine (AZT) metabolism in mice, thus significantly increasing this drug's half-life, may be another means by which the combination may be more effective. Finally, studies with Fv infection in (B10.11x 11.By)F 1 mice using IFN- $\alpha-A / D$ in combination with D4T were recently completed (23). These studies, like those cited above, also suggested a synergistic effect. It was also observed that the IFN- $\alpha-A / D$ treatment enhanced the NK cell activity in the animals, and, in combination with D4T, this NK cell activity was further increased (23). Earlier reported studies by Sidwell et al (17) and by Black et al (24) indicated that NK cell activity may be an important factor in the in vivo retrovirus disease inhibition exerted by biological response modifiers.

Potential as therapies for HIv infections: The future of IFNS as therapies for AIDS appears to be in their use in combination with more specific anti-HIV therapies. Table 2 summarizes the retrovirus experiments with the combinations that have been described to date. Only in the study by Fazely et al (25), using the combination of IFN- $\alpha$ and AZT against simian immunodeficiency virus infections in rhesus monkeys, was the treatment not considered effective. In this study, however, the combination treatment did appear to depress the level of virus replication more effectively than either substance used alone. The studies of the effects of IFN- $\alpha$ in cats infected with feline leukemia virus (FeLv) have been quite revealing (26-28): the combination of IFN- $\alpha$ with AZT was absolutely required for a significant antiviral effect to be seen, and the inclusion of adoptive transfer of activated lymphocytes was required to reverse an established FeLV infection. Also of considerable importance was the observation that the development of neutralizing antibody to the recombinant human IFN- $\alpha$ appeared to limit the antiviral efficacy of this cytokine $(26,27)$. Such an effect has also been reported in human patients receiving IFN- $\alpha$ for treatment of neoplastic disease (26).

\section{INTERLEUKINS}

Interleukins (ILS) have been defined as "proteins produced by leukocytes which function during inflammatory responses by acting on leukocytes or other targets" by the International Union of Immunological Societies Nomenclature Committee (29). The number of ILs discovered has increased steadily, with at least 11 known to date. Of the ILS, IL-2 has been studied most extensively for antiviral activities. Human recombinant IL-2 is now available commercially and has been used in most of the studies cited.

Mechanism of antiviral effects: $\mathrm{IL}-2$, a 13 to $15 \mathrm{kDa}$ glycoprotein derived from $\mathrm{CD} 4+$ and $\mathrm{CD} 8+\mathrm{T}$ lymphocytes in response to mitogenic or antigenic stimuli, is required for the development of various cell-mediated immune functions that are known to be deficient in AIDS patients. These functions include support of the proliferation and differentiation of $\mathrm{T}$ and $\mathrm{B}$ lymphocytes and the enhancement of NK cell activity (30). IL-2 production is defective in patients infected with HIV (31).

Potential for therapy of HIV infections: Table 3 summarizes the retrovirus inhibitory effects of the ILs. The Zeidner et al study (26) employing IL-2 alone or in combination with AZT in treating FeLV in cats was run using the same conditions as the previously cited study with IFN- $\alpha$ and AZT. Using the latter combination, a synergistic effect was seen in enabling the animals to 
resist the viral challenge, whereas when $\mathrm{IL}-2$ was used alone, no protection was rendered, and using IL-2 in combination with AZT appeared to be less effective than using AZT alone. The most potent action of IL-2 appears to be its ability to restore the immunological responses of peripheral blood lymphocytes from AIDS patients $(32,33)$. NK cell activity was consistently the immune parameter that was most strongly affected by recombinant human IL-2 treatment, an observation also made by Mead et al (34) in a phlebovirus infection model in which marked immunosuppression occurs. Sayers et al (35) also demonstrated activation of NK cells following treatment with human recombinant $\mathrm{IL}-2$ in mice. This potential to restore AIDS-related immunosuppression is provocative; caution should be used, however, in extrapolating in vitro data to potential in vivo efficacy, especially when one must consider pharmacokinetics and potential toxicity of IL-2. Adverse effects associated with $\mathrm{IL}-2$ were recently reviewed (2).

A study of interest regarding IL-2 was reported by Finberg et al (36). Previously, it was shown that the binding of gp 120 from HIV leads to IL-2 receptor expression on monocytes, and cross-linking of $\mathrm{CD} 4$ leads to IL-2 receptor expression in T cells. In the Finberg et al study, a genetically engineered fusion toxin consisting of a fragment of diphtheria toxin, DAB486, was bound to IL-2 sequences, which resulted in a selective killing of HIV-infected $\mathrm{T}$ cells. Two doses of the cytotoxin were used, and both markedly reduced the number of infected cells while not appreciably affecting uninfected $\mathrm{T}$ cells. The DAB486 IL-2 has reportedly been used safely in patients with $\mathrm{IL}-2$ receptor expression malignancies (36). This unique approach of using targeted toxins appears to have promise as a means of treating HIVinfected individuals.

The final study (37) cited in Table 3 involves the use of recombinant human $\mathrm{IL}-7$, a $25 \mathrm{kDa}$ glycoprotein identified as a growth factor that stimulates the proliferation of B cell precursors (38) as well as thymocytes and mature $\mathrm{T}$ lymphocytes, and has a variety of other biological activities (39). In the study cited, the splenomegaly as well as the number of spleen focusforming virus units and viral messenger RNA induced by the FV complex in mice were significantly reduced by subcutaneous $\mathrm{IL}-7$ treatment. Mean survival time of the animals was significantly increased. IL-7 treatment also restored NK cell activity, IL-6 and IFN- $\gamma$ to normal levels in the infected animals. The treatments were apparently reasonably well tolerated.

\section{TUMOUR NECROSIS FACTOR}

Tumour necrosis factors (TNFS) are proteins produced by activated macrophages and lymphocytes and a number of other cells that destroy tumour tissue in a tumour-bearing animal (40). TNFs have recently undergone considerable scrutiny as a potential antiviral substance.
TABLE 3

Retrovirus inhibition studies using interleukins

\begin{tabular}{lc} 
Action & Reference \\
\hline IlL-2 used alone moderately reduced & 26 \\
circulating FeLV viral core protein in cats; & \\
in combination with AZT, viral core protein & \\
was markedly reduced, but less than with \\
AZT alone \\
rIL-2 enhanced the NK cell and CMV-specific \\
cytotoxic Iymphocyte activities of PBLs \\
taken from AIDS patients \\
IIL-2 increased in vitro the NK cell and \\
mitogen and alloantigen dependent \\
proliferative responses of PBLs taken from \\
AIDS patients \\
IL-2 fused to DAB486 toxin selectively killed \\
HIV- 1-infected cells and inhibited produc- \\
tion of viral protein and infectious virus \\
IL-6 induced HIV expression alone and \\
synergistically with TNF- $\alpha$ in infected \\
monocytic cells \\
IL-4 was weakly inhibitory, and IL-2 and IL-6 \\
were not inhibitory to HIV p24 antigen \\
Production in macrophage cultures \\
IL-6 increased HIV p24 expression in U1 cells. \\
IL-3, IL-8 had no effect \\
rIL-7 inhibited the murine disease induced by \\
the Friend virus; NK cell activity, IL-6 and \\
IFN- $\gamma$ levels were restored to normal
\end{tabular}

AZT Zidovudine: CMV Cytomegalovirus; FeLV Feline leukemia virus; IFN Interferon; IL Interleukin; NK Natural killer; PBLS Peripheral blood lymphocytes; $r$ Recombinant: TNF Tumour necrosis factor

Mechanism of antiviral effects: As with the other cytokines, TNF has a wide spectrum of biological activities. TNF produced by macrophages and monocytes is designated TNF- $\alpha$; TNF- $\beta$ is lymphotoxin material produced by activated lymphocytes. TNF $-\alpha$ and TNF- $\beta$ have similar biological properties.

This cytokine is not generally considered to be primarily an antiviral mediator, but has been shown to exert antiviral activity both by suppressing viral replication and by eliminating HIV-infected cells. Wong et al (41) have noted that TNF may function indirectly in antiviral defence by making infected cells more easily recognized by cytotoxic $T$ cells. They cite the induction of viral antigen expression reported by Folks et al (42) and by Yagi et al (43), which results in an increase in viral antigens on the surfaces of latently infected cells. Wong et al (41) reason that the appearance of these antigens, concomitant with increased major histocompatibility complex class 1 expression, which is also stimulated by TNF (44), "signal the immune system that the host cell should be destroyed". In line with these observations are also those of Poli et al (39), who reported that the combination of TNF- $\alpha$ and IL- 6 synergistically induced HIV expression. This latter group and others (45-47) have shown that TNF- $\alpha$ may work in activating HIV expression through activation of $\mathrm{NF}-\mathrm{kB}$, a 
TABLE 4

Retrovirus inhibition studies using tumour necrosis factor (TNF)

\begin{tabular}{|c|c|}
\hline Action & Reference \\
\hline $\begin{array}{l}\text { TNF- } \alpha \text { had a cytocidal effect on cells } \\
\text { chronically infected with HIV and } \\
\text { enhanced HIV replication }\end{array}$ & 67 \\
\hline $\begin{array}{l}\text { TNF pretreatment weakened HIV-infected } \\
\text { cells }\end{array}$ & 41 \\
\hline $\begin{array}{l}\text { TNF treatment of a promonocyte cell line } \\
\text { chronically infected with HIV induced viral } \\
\text { antigen expression }\end{array}$ & 42 \\
\hline $\begin{array}{l}\text { TNF treatment enhanced murine SL3-3 } \\
\text { retrovirus expression in cells }\end{array}$ & 43 \\
\hline $\begin{array}{l}\text { TNF- } \alpha \text { moderately lessened HIV p24 antigen } \\
\text { expression in HUT78 and CD4+ cells; } \\
\text { marked virus inhibition and killing of HIV- } \\
\text { infected cells occurred in combination } \\
\text { with IFN- } \gamma\end{array}$ & 64 \\
\hline $\begin{array}{l}\text { TNF + IL-6 synergistically induced HIV } \\
\text { expression in UI cells }\end{array}$ & 39 \\
\hline $\begin{array}{l}\text { TNF- } \alpha \text {, TNF- } \beta \text { did not affect HIV p } 24 \text { antigen } \\
\text { production in cultured macrophages }\end{array}$ & 3 \\
\hline
\end{tabular}

HIV Human immunodeficiency virus: IFN Interferon; IL Interleukin

cellular transcription factor that mediates tissue-specific and gene function. The weakening of virus infected cells (41) would lessen the capability of the cells to synthesize new virus. Another possible mechanism in the antiviral activity of TNF lies in the ability of TNF- $\alpha$ and TNF- $\beta$ to induce $2^{\prime}, 5^{\prime}$ A synthetase (41), which was described earlier in this review as being a possible mechanism for IFN's antiviral activity. The synergistic effects of TNF- $\alpha$ used in combination with IFN- $\gamma$ appear to indicate the most promising role for TNF in treating retroviral diseases.

Potential for therapy of HIV infections: The effects of TNF on retrovirus infections are summarized in Table 4. Overall, the effects of TNF have been more on the negative side, suggesting this cytokine may not be an appropriate therapy for AIDS. Numerous observations have been made that TNF can be quite toxic (48). There is also the spectre that TNF may actually play a role in development of AIDS, since the cytokine induces wasting, B cell activation, $T$ cell death, oligodendrocyte killing and inflammation (49), all of which occur in AIDS. The previously cited activation of HIV expression (42), shown as approximately a $400 \%$ increase in the infected cells, may play a role in the mechanism of pathogenesis of HIV infection. Sastry et al (50) have demonstrated that the HIV tat gene induces TNF- $\beta$ messenger RNA and protein from Raji cells, implicating TNF- $\beta$ as a mediator of HIV's stimulatory effects on Kaposi's sarcoma.

There appears to be much more work needed with TNF before the potentials of this cytokine as a therapy for AIDS can be defined. More work in animal models of retroviral disease would be especially useful.

\section{COLONY STIMULATING FACTOR}

Colony stimulating factors (CSFS) are proteins that stimulate the in vitro clonal growth of bone marrow cells (51). The name reflects the early observation that CSFS promote the formation of granulocyte or monocyte colonies in semi-solid medium. There are four so-called 'established' CSFS, namely, multipoietin/IL-3, granulocyte-macrophage CSF (GM-CSF), macrophage-specific CSF (M-CSF) and granulocyte-specific CSF (G-CSF).

Mechanisms of antiviral effects: Like other cytokines, CSFS have a variety of immunological actions, but are best known for their dependency on the presence of other cytokines (51). GM-CSF has a significant effect on bone marrow progenitor cells; this includes increasing the production of granulocytes, monocytes, eosinophils and megakaryocytes (2). The cytokine also increases the number of mature polymorphonuclear leukocytes and monocytes in the peripheral blood, and stimulates the function of mature phagocytic cells (2). These immunological effects have engendered considerable interest in the material as a potential treatment for a variety of infectious diseases. G-CSF and M-CSF also have immunomodulatory effects, but to a lesser extent and in a narrower spectrum than GM-CSF.

Potential for therapy of HIV infections: Studies have reported on most of the established CSFs regarding their effect on HIV infections (Table 5), but GM-CSF appears to have the most significant activity. The enhancement of production of bone marrow precursor cells cited above has led to GM-CSF being studied as a supplementary drug in the treatment of AIDS, since it may counteract the marrow suppression due to HIV infection or occurring as a result of AZT therapy (52). In vitro studies performed by Kaplan et al (53) demonstrated that GM-CSF enhanced both spontaneous and stimulated production of reactive oxygen intermediates in monocytes taken from AIDS patients. This effect essentially doubled the cytotoxic action of monocytes against Candida albicans. These results suggest that GM-CSF may have the ability to enhance the immune defence of AIDS patients against some types of infection.

Like TNF, the reported effects of this group of cytokines appear to be somewhat conflicting, with both inhibition and enhancement of in vitro HIV replication seen. Since $T$ lymphocytes are among the cells that produce GM-CSF, Perno et al (52) have speculated that this cytokine may play a central role in the progression of HIV infection to AIDS. GM-CSF, produced by T cells in response to antigenic stimulation, may also enhance HIV replication in macrophages leading to the spread of virus to more T cells. As noted in Table 5, however, there are some studies $(54,55)$ in which inhibition of HIV was seen with GM-CSF. The study by Hammer et al (54) measured the replication of laboratory strains of the virus in alveolar macrophages, with inhibition of virus occurring.

The synergistic enhancement of the anti-HIV effects 
of AZT and related drugs by GM-CSF $(52,54,57)$ provides an additional potential use for this cytokine. This effect may be a result of GM-CSF increasing cellular levels of the triphosphate metabolite of these drugs $(52,56,57)$ due to an induced increase in thymidine kinase. Cells stimulated with GM-CSF also have been shown to have higher levels of intracellular AzT, which would suggest that GM-CSF may also enhance cell entry of AZT and related drugs.

As with TNF, much additional work with GM-CSF particularly needs to be done.

\section{SUMMARY}

Cytokines are gaining much increased attention as possible therapies for AIDS. A major boost in these considerations has been the increasing availability of large amounts of purified materials provided through advances in genetic engineering. The cytokines that have been most intensively studied as antiviral therapies include the IFNs, the ILs (particularly IL- 2 but also IL-4, IL-6 and IL-7), TNF and the CSFs (particularly GM-CSF and to a lesser extent G-CSF and M-CSF). In vitro antiviral studies have been run with all of these cytokines; in vivo experiments have been primarily limited to the IFNS and ILs. The greatest promise of the cytokines appears to be when they are used in combination with more standard antiviral agents or with selected other cytokines. The targeted cytokine/toxin therapy using IL-2 has yielded results indicating a considerable potential as an AIDS therapy. Caution is urged in the application of the experimental data cited to the clinical situation, due to the many diverse biological properties of these regulatory substances and the interweaving of their effects with other cytokines.

\section{REFERENCES}

1. Balkwill FR, Burke F. The cytokine network. Immunol Today 1989;10:299-304.

2. Roilides E, Pizzo PA. Modulation of host defenses by cytokines: Evolving adjuncts in prevention and treatment of serious infections in immunocompromised hosts. Clin Infect Dis 1992;15:508-24.

3. Kornbluth RS, Ikl PS, Munis JR, Cleveland PH, Richman DD. Interferons and bacterial lipopolysaccharide protect macrophage from productive infection by human immunodeficiency virus in vitro. J Exp Med 1989; 169:1137-51.

4. Pitha PM, Wival NA, Fernie BF, Harper HP. Effect of interferon on murine leukemia virus infection. IV. Formation of non-infectious virus in chronically infected cells. J Gen Virol 1979;42:467-80.

5. Aboud M, Kimchi R, Bakhanashvili M, Salzberg S. Intracellular production of virus particles and viral components in NIH/3T3 cells chronically infected with Moloney murine leukemia virus: Effect of interferons. J Virol 1981;40:830-8.

6. Ho DD, Hartshorn KL, Rota TR, et al. Recombinant human interferon alpha-A suppresses HTLV-III replication in vitro. Lancet 1985; :602-4

7. Poli G, Orenstein JM, Kinder A, Folks TM, Fauci AS. Interferon-alpha but not AZT suppresses HIV expression

\section{TABLE 5 \\ Retrovirus inhibition studies using colony stimulating factor (CSF)}

\begin{tabular}{|c|c|}
\hline Action & Reference \\
\hline $\begin{array}{l}\text { GM-CSF enhanced production of reactive } \\
\text { oxygen intermediates in monocytes from } \\
\text { AIDS patients, doubled cytotoxic action of } \\
\text { monocytes versus Candida albicans }\end{array}$ & 53 \\
\hline $\begin{array}{l}\text { GM-CSF, M-CSF enhanced monocyte/macro- } \\
\text { phage lineage cells' capacity for HIV } \\
\text { replication, but GM-CSF acted synergistically } \\
\text { with AZT, D4T, related analogues to suppress } \\
\text { the infection }\end{array}$ & 52 \\
\hline $\begin{array}{l}\text { GM-CSF increased rate of HIV replication in a } \\
\text { chronically infected promonocyte cell line }\end{array}$ & 68 \\
\hline $\begin{array}{l}\text { GM-CSF increased rate of HIV replication in } \\
\text { monocytes }\end{array}$ & 69 \\
\hline $\begin{array}{l}\text { GM-CSF + AZT synergistically inhibited HIV in } \\
\text { macrophages }\end{array}$ & 54 \\
\hline $\begin{array}{l}\text { GM-CSF, M-CSF enhanced HIV replication in } \\
\text { monocyte/ macrophage cells; GM-CSF } \\
\text { increased AZT anti-HIV efficacy, reduced } \\
\text { efficacy of ddC, ddl, PMEA. M-CSF } \\
\text { reduced efficacy of AZT, ddC, ddl, PMEA. } \\
\text { G-CSF had no effect, AZT-triphosphate } \\
\text { levels were increased in presence of GM-CSF }\end{array}$ & 56,57 \\
\hline $\begin{array}{l}\text { GM-CSF inhibited replication of HIV in a mono- } \\
\text { cytoid cell line }\end{array}$ & 55 \\
\hline $\begin{array}{l}\text { GM-CSF + IFN-g synergistically inhibited HIV } \\
\text { replication in U937 cells }\end{array}$ & 70 \\
\hline $\begin{array}{l}\text { M-CSF enhanced HIV production by } \\
\text { monocyte/macrophage cells }\end{array}$ & 71 \\
\hline $\begin{array}{l}\text { M-CSF had virtually no effect, and GM-CSF had } \\
\text { a moderately inhibitory effect, on HIV p24 } \\
\text { antigen production in cultured macrophages }\end{array}$ & 3 \\
\hline \multicolumn{2}{|c|}{$\begin{array}{l}\text { AZT Zidovudine: ddC } 2 \text {, 3'-dideoxycytidine; ddl 2, 3'-dideoxyinosine; HI } \\
\text { Human immunodeficiency virus; GM-CSF Granulocyte macrophage } \\
\text { CSF; M-CSF Macrophage-specific CSF; PMEA 9-(2-phosphonylmethoxy } \\
\text { ethyl)adenine }\end{array}$} \\
\hline
\end{tabular}

in chronically infected cell lines. Science 1989;244:575-7.

8. Aboud M, Shoor R, Salzber S. An effect of interferon on the uncoating of murine leukemia virus not related to antiviral state. J Gen Virol 1980;51:425-9.

9. Bilello JA, Wivel NA, Pitha PM. Effect of interferon on the replication of mink cell focus-inducing virus in murine cells: Synthesis, processing, assembly, and release of viral proteins. J Virol 1982;43:213-22.

10. Smith MS, Thresher RJ, Pagano JS. Inhibition of human immunodeficicncy virus type I morphogenesis in T cells by alpha interferon. Antimicrob Agents Chemother 1991;35:62-7.

11. Friedman RM. Antiviral activity of interferons. Bacteriol Rev 1977;41:543-67.

12. Sen GC. Biochemical pathways in interferon-action. Pharmacol Ther 1984;24:235-57.

13. Naso RB, Wu YC, Edbauer CA. Antiretroviral effect of interferon: Proposed mechanism. J Interferon Res 1982:2:75-96.

14. Samuel CE. Interferon induction of the antiviral state: Proteins induced by interferons and their possible roles in the antiviral mechanisms of interferon action. In: Pfeffer LM, ed. Mechanisms of Interferon Actions. Boca Raton: CRC Press, 1987:111-30.

15. Ruprecht RM, Chou TC, Chipty F, et al. Interferon-alpha and $3^{\prime}$-azido- $3^{\prime}$-deoxythymidine are highly synergistic in 
mice and prevent viremia after acute retrovirus exposure. J Acquir Immune Defic Syndr 1990;3:591-600.

16. Ghaffar A, Mayer EP, Barnhart DC, et al. Cross-species antiviral activity of a recombinant human alpha-interferon hybrid. Ann N Y Acad Sci 1992;653:314-22.

17. Sidwell RW, Morrey JD, Okleberry KM, Burger RA, Warren RP. Immunomodulator effects on the Friend virus infection in genetically defined mice. Ann N Y Acad Sci 1993;685:432-46.

18. Heberman RB, Djeu JY, Ortaldo JR, Holden HT, West WH, Bonnard GD. Role of interferon with augmentation of natural and antibody-dependent cell-mediated cytotoxicity. Cancer Treat Res 1978;62:1893-6.

19. Britt WJ, Chesebro B. H-2D control of recovery from Friend virus leukemia: $\mathrm{H}-2 \mathrm{D}$ region influences the kinetics of the T lymphocyte response to Friend virus. J Exp Med 1983;157:1736-45.

20. Chesebro B, Wehrly K. Studies on the role of the host immune response in recovery from Friend virus leukemia. II. Cell-mediated immunity. J Exp Med 1976;143:85-99.

21. Miyazawa M, Nishio J, Chesebro B. Genetic control of T cell responsiveness to the Friend murine leukemia virus envelope antigen. J Exp Med 1988;168:1587-605.

22. Shafik HM, Notka MA, Pollard RB. Recombinant human interferon beta protects against zidovudine-induced genetic damage in AIDS patients. Antiviral Res 1991;16:205-12.

23. Sidwell RW, Morrey JD, Warren RP, et al. Effect of the combination of human recombinant interferon- $\alpha \mathrm{A} / \mathrm{D}$ and 2', $3^{\prime}$-didehydro-2', $3^{\prime}$-dideoxythymidine (D4T) on murine retrovirus disease. Recent Adv Chemother 1993. (In press)

24. Black PL, McKinnon KM, Wooden SL, Ussery MA. Antiviral activity of the interferon inducer poly [I,C]-LC in a murine AIDS model: Requirement for augmentation of natural killer cell activity and synergy with oral AZT. Recent Adv Chemother 1992;II:1918-9.

25. Fazely F, Haseltine WA, Rodger RF, Ruprecht RM. Post exposure chemoprophylaxis with ZDV or ZDV combined with interferon- $\alpha$ : Failure after inoculating rhesus monkeys with a high dose of SIV. J Acquir Immune Defic Syndr 1991:4:1093-7.

26. Zeidner NS, Rose LM, Mathiason-DuBard CK, et al. Zidovudine in combination with alpha interferon and interleukin-2 as prophylactic therapy for FeLV-induced immunodeficiency syndrome. J Acquir Immune Defic Syndr 1990;3:787-96.

27. Zeidner NS, Mathiason-DuBard CK, Hoover EA. Reversal of established FeLV-FAIDS infection after adoptive transfer of activated lymphocytes in combination with AZT and alpha interferon. Antiviral Res 1992;17(Suppl 1):86.

28. Zeidner NS, Myles MH, Mathiason-DuBard CK, Dreitz MJ, Mullins JI, Hoover EA. Alpha interferon (2b) in combination with zidovudine for the treatment of presymptomatic feline leukemia virus-induced immunodeficiency syndrome. Antimicrob Agents Chemother 1990;34:1749-56.

29. Dawson MM. Introduction. In: Lymphokines and Interleukins. Boca Raton: CRC Press, 1991:xi.

30. Kuziel WA, Greene WC. Interleukin-2. In: Thomson A, ed. The Cytokine Handbook. New York: Academic Press, 1991:83-102.

31. Lane HC, Depper JM, Greene WC, Whalen G, Waldmann TA, Fauci AS. Qualitative analysis of immune function in patients with the acquired immunodeficiency syndrome: Evidence for a selective defect in soluble antigen recognition. N Engl J Med 1985;313:79-84.

32. Rook AH, Masur H, Lane HC, et al. Interleukin-2 enhances the depressed natural killer and cytomegalovirus-specific cytotoxic activities of lymphocytes from patients with the acquired immune deficiency syndrome. J Clin Invest 1983;72:398-403.

33. Lifson JD, Benike CJ, Mark DF, Koths K, Engleman EG. Human recombinant interleukin-2 partly reconstitutes deficient in vitro immune responses of lymphocytes from patients with AIDS. Lancet 1984;i:698-702.

34. Mead JR, Burger RA, Yonk LJ, et al. Effect of human recombinant interleukin 2 on Punta Toro virus infections in C57BL/6 mice. Antiviral Res 1991;15:331-40.

35. Sayers T, Rossiter H, Chung J, Hren A, Armerding D. In vivo activation of murine natural killer cell functions by human recombinant DNA interleukin-2. Immunobiology 1985; 169:303-18.

36. Finberg RW, Wahl SM, Allen JB, et al. Selective elimination of HIV-1-infected cells with an interleukin-2 receptor-specific cytotoxin. Science 1991;252:1703-5.

37. Lu L, Zhou Z, Wu B, et al. Influence of recombinant human interleukin (IL)-7 on disease progression in mice infected with Friend virus complex. Int J Cancer 1992;52:261-5.

38. Namen AE, Schmierer AE, March CJ, et al. B cell precursor growth-promoting activity. Purification and characterization of a growth factor active on lymphocyte precursors. J Exp Med 1988;167:988-1002.

39. Poli G, Bressler P, Kinder A, et al. Interleukin 6 induces human immunodeficiency virus expression in infected monocytic cells alone and in synergy with tumor necrosis factor by transcriptional and post-transcriptional mechanisms. J Exp Med 1990;172:151-8.

40. Old LJ. Tumor necrosis factor. In: Bonavida B, Granger B, eds. TNF: Structure, Mechanism of Action, Role in Disease and Therapy. New York: Karger, 1990:1-30.

41. Wong GHW, Kamb A, Goeddel DV. Antiviral properties of TNF. In: Beutler B, ed. Tumor Necrosis Factors: The Molecules and Their Emerging Role in Medicine. New York: Raven Press, 1990:371-81.

42. Folks TM, Clouse KA, Justement J, et al. Tumor necrosis factor $\alpha$ induces expression of human immunodeficiency virus in a chronically infected T-cell clone. Proc Natl Acad Sci USA 1989;86:2365-8.

43. Yagi MJ, Holland JF, Bekesi JG. Tumor necrosis factor enhances murine SL3-3 retrovirus replication. J Clin Lab Immunol 1987;24:129-34.

44. Collins T, Lapierre LA, Fiers W, Strominger JL, Pober JS. Recombinant human tumor necrosis factor increases mRNA levels and surface expression of HLA-A, B antigens in vascular endothelial cells and dermal fibroblasts in vitro. Proc Natl Acad Sci USA 1986;83:446-50.

45. Osborn L, Kunkel S, Nabel GJ. Tumor necrosis factor $\alpha$ and interleukin 1 stimulate the human immunodeficiency virus enhancer by activation of the nuclear factor $\mathrm{kB}$. Proc Natl Acad Sci USA 1989;86:2336-9.

46. Duh EJ, Maury WJ, Folks TM, Fauci AS, Robson AB. Tumor necrosis factor $\alpha$ activates human immunodeficiency virus type 1 through induction of nuclear factor binding to the NF-kB sites in the long terminal repeat. Proc Natl Acad Sci USA 1989;86:5974-7.

47. Okamoto T, Matsuyama T, Mori Y, et al. Augmentation of human immunodeficiency virus type 1 gene expression by tumor necrosis factor alpha. AIDS Res Hum Retroviruses 1989;5:131-7.

48. Manogue KR, VanDeventer SJH, Cerami A. Tumor necrosis factor alpha or cachectin. In: Thomson A, ed. The Cytokine Handbook. New York: Academic Press, 1991:241-56.

49. Ruddle NH, Turetskaya RL. Tumor necrosis factor beta. 
In: Thomson A, ed. The Cytokine Handbook. New York: Academic Press, 1991:257-67.

50. Sastry KJ, Reddy RHR, Pandito R, Totpal K, Aggarwal BB. HIV-1 tat gene induces tumor necrosis factor- $\beta$ (lymphotoxin) in a human B-lymphoblastoid cell line. J Biol Chem 1990;265:20091-3.

51. Garland JM. Colony stimulating factors. In: Thomson A. ed. The Cytokine Handbook. New York: Academic Press, 1991:269-300.

52. Perno CF, Yarchoan R, Cooney DA, et al. Replication of human immunodeficiency virus in monocytes: Granocyte/macrophage colony stimulating factor (GM-CSF) potentiates viral production yet enhances the antiviral effect mediated by 3 '-azido-3'-deoxythymidine (AZT) and other nucleoside congeners of thymidine. J Exp Med 1989;169:933-5.

53. Kaplan SS, Zdziarski UE, Basford RE, Wing E, Shadduck RK. Effect of in vivo recombinant human granulocyte-macrophage colony stimulating factor on peripheral blood granulocyte function. Clin Res 1988;36:566A.

54. Hammer SM, Gillis JM, Pinkston P, Rose RM. Effect of zidovudine and granulocytc-macrophage colony-stimulating factor on human immunodeficiency virus replication in alveolar macrophages. Blood 1990;75: 12 15-9.

55. Groopman J, Mitsuyasu RT, DeLeo MJ, Oette DH, Golde DW. Effect of recombinant human granulocytemacrophage colony-stimulating factor on myelopoiesis in the acquired immunodeficiency syndrome. N Engl J Med 1987;317:593-8.

56. Perno CF, Foli A, Hao Z, et al. Bone marrow stimulatory cytokines modulate the anti-HIV activity of nucleoside analogues in cultures of monocyte/macrophages. Antiviral Res 1992;13(Suppl 1):85.

57. Perno CF, Calio R, Rocchi G, Balzafini J, Broder S, Yarchoan R. In vitro modulation of the activity of anti-HIV drugs in monocytes by GM-CSF and other cytokines. Antiviral Res 1990;13(Suppl 1):94.

58. Hartshorn KL, Sandstrom EG, Neumeyer D, et al. Synergistic inhibition of human T-cell lymphotropic virus type III replication in vitro by phosphonoformate and recombinant alpha-A interferon. Antimicrob Agents Chemother 1986;30: 189-91.

59. Hartshorn KL, Vogt MW, Chou T-C, et al. Synergistic inhibition of human immunodeficiency virus in vitro by azidothymidine and recombinant alpha-A interferon. Antimicrob Agents Chemother 1987;31:168-92.

60. Ito M, Baba M, Shigeta S, et al. Synergistic inhibition of human immunodeficiency virus type 1 replication in vitro by 1-[(2-hydroxyethoxy)methyl]-6-phenylthiothymine and recombinant alpha interferon. Antiviral Res $1991 ; 15: 323-30$

61. Johnson VA, Merrill DP, Chou T-C, Hirsch MS. Human immunodeficiency virus type 1 inhibitory interactions between protease inhibitor Ro 31-8959 and zidovudine, $2^{\prime}, 3^{\prime}$-dideoxycytidine, or recombinant interferon $\alpha A$ against zidovudine-sensitive or -resistant HIV-1 in vitro. $\mathrm{J}$ Infect Dis 1992;166:1143-6.

62. Dubreuil M, Sportza L, D'Addario M, et al. Inhibition of HIV- 1 transmission by interferon and $3^{\prime}$-azido- $3^{\prime}$ deoxythymidine during de novo infection of promonocytic cells. Virology 1990;179:388-94.

63. Kort JJ, Eiseman JL. Interferon-gamma: A potent antiviral agent targeting macrophages infected with LP-BM5 murine leukemia virus, the causative agent of 'AIDS' in mice. Can J Infect Dis 1992;3(Suppl B): 115B-22B.

64. Wong GHW, Krowka JF, Stites DP, Goeddel DV. In vitro anti-human immunodeficiency virus activities of tumor necrosis factor $-\alpha$ and interferon- $\gamma$. J Immunol 1988; 140:120-4.

65. Lu L, Shen RN, Shou SZ, et al. Synergistic effect of human lactoferrin and recombinant murine interferon- $\gamma$ on disease progression in mice infected with the polycythemia-inducing strain of the Friend virus complex. Int J Hematol 1991;54:1 17-24.

66. Rosenwirth B, Besemer J. Quantitatively different effects of cytokines on chronic HIV-1 infection. Antiviral Res 1990;13(Suppl 1):95.

67. Matsuyama T, Hamamoto Y, Soma G, Mizuno D, Yamamoto N, Kobayashi N. Cytocidal effect of tumor necrosis factor on cells chronically infected with immunodeficiency virus (HIV): Enhancement of HIV replication. J Virol 1989;63:2504-9.

68. Folks TM, Justement J, Kinter A, Dinarello CA, Fauci AS. Cytokine-induced expression of HIV-1 in a chronically infected promonocyte cell line. Science 1987;238:800-2.

69. Meltzer MS, Gendelman HE. Effects of colony stimulating factors on the interaction of monocytes and the human immunodeficiency virus. Immunol Lett 1988;19:193-8.

70. Hammer SM, Gillis JM, Groopman JE, Rose RM. In vitro modification of human immunodeficiency virus infection by granulocyte-macrophage colony-stimulating factor and gamma interferon. Proc Natl Acad Sci USA 1986;83:8734-6.

71. Gendelman HE, Orenstein JM, Martin MA, et al. Efficient isolation and propagation of human immunodeficiency virus on recombinant colony-stimulating factor 1-treated monocytes. J Exp Med 1988;167:1428-35. 


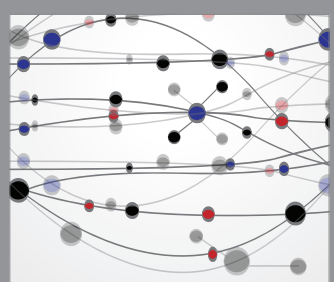

The Scientific World Journal
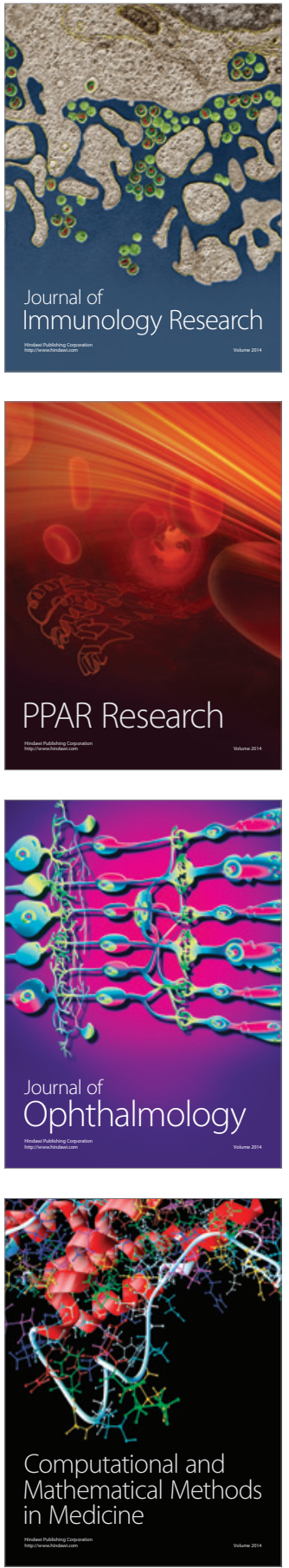

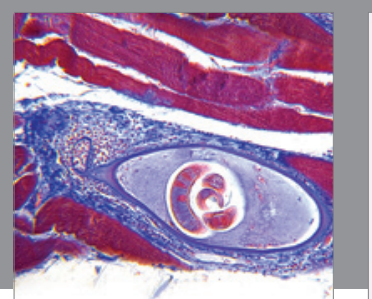

Gastroenterology Research and Practice

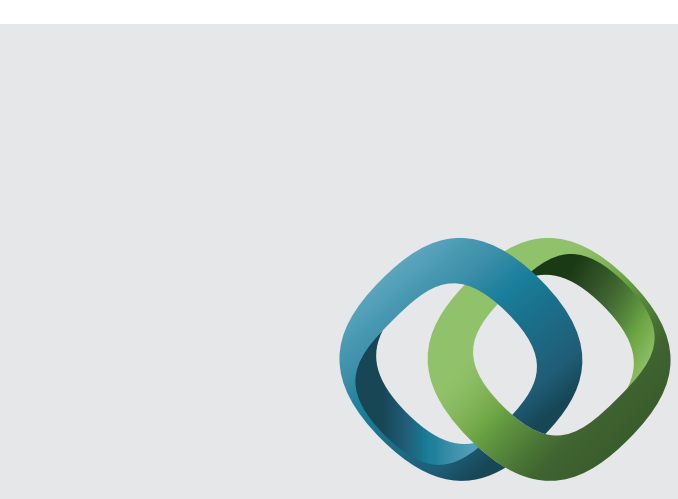

\section{Hindawi}

Submit your manuscripts at

http://www.hindawi.com
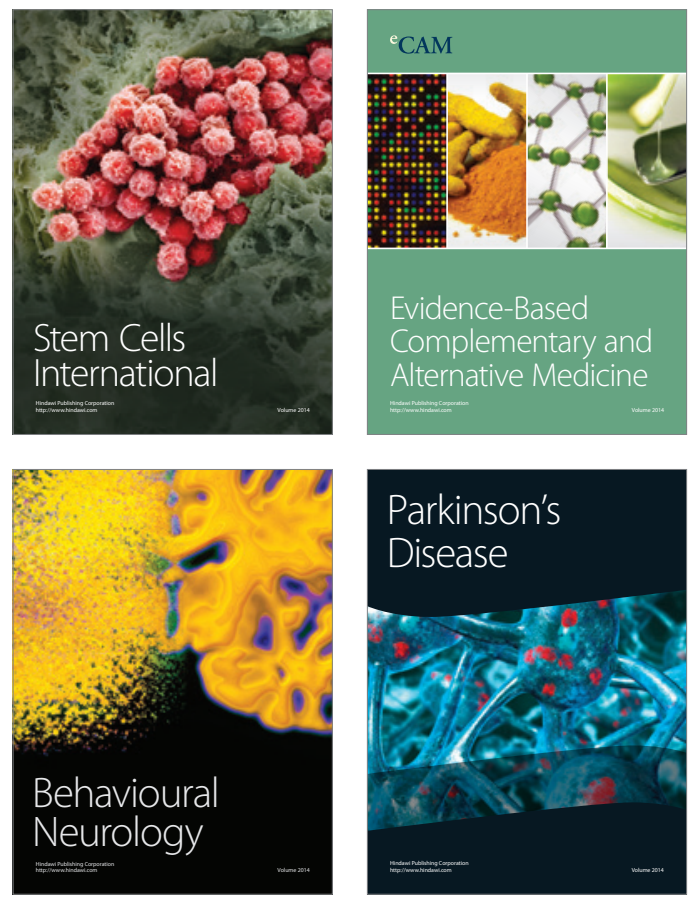
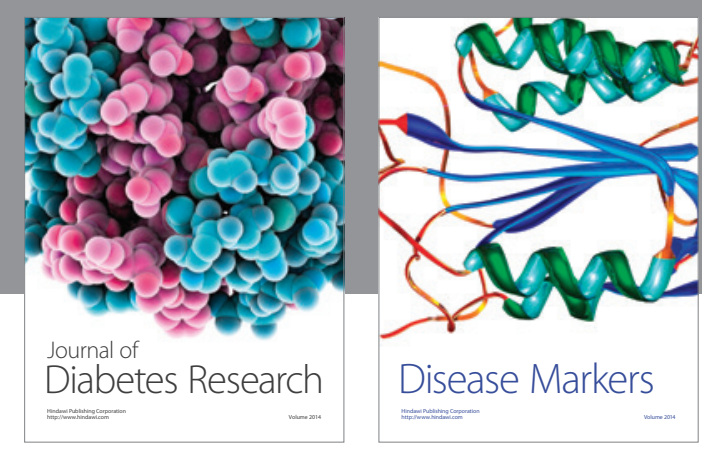

Disease Markers
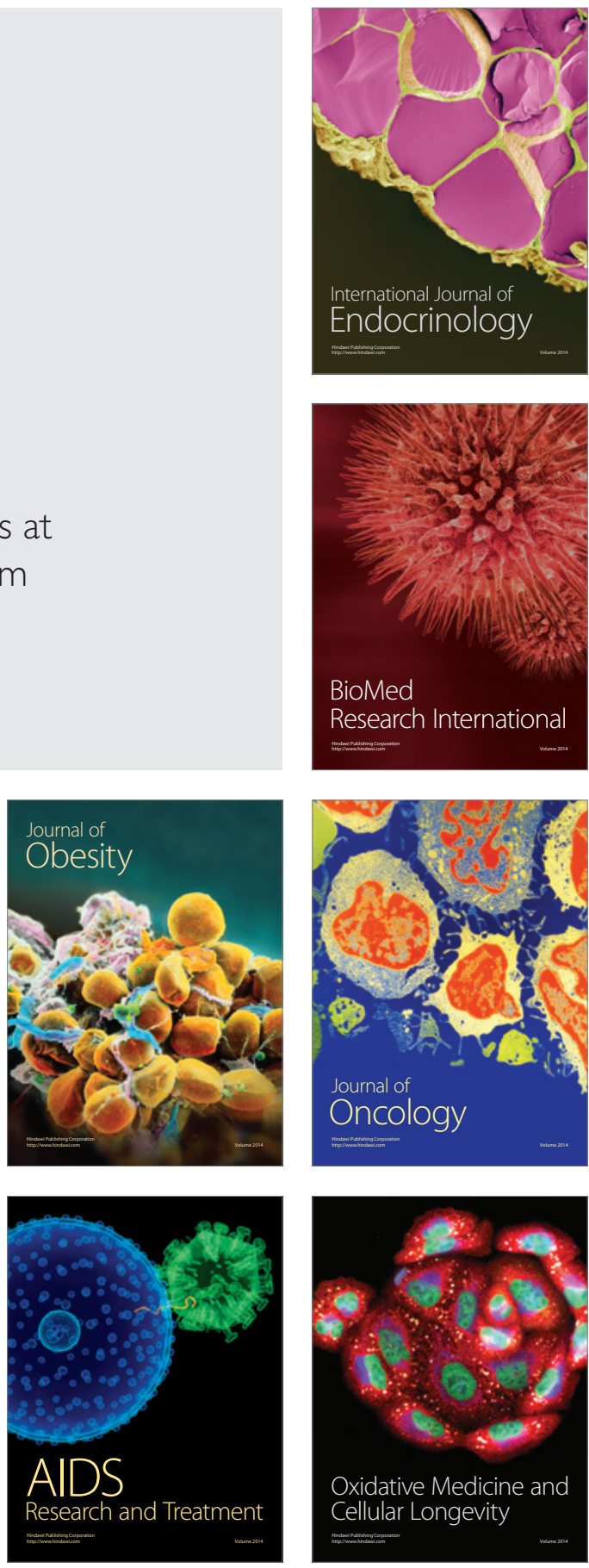